\title{
FGFR1OP/FGFR1 Fusion Protein
}

National Cancer Institute

\section{Source}

National Cancer Institute. FGFR1OP/FGFR1 Fusion Protein. NCI Thesaurus. Code C99695.

A fusion protein encoded by the FGFR1OP/FGFR1 fusion gene. This protein is comprised of the LIS1 homology domain of the FGFR1 oncogene partner protein followed by the tyrosine kinase domains of the basic fibroblast growth factor receptor 1 . 